\title{
PERLINDUNGAN HUKUM TERHADAP HAK RUMAH SAKIT SWASTA ATAS KETERLAMBATAN PEMBAYARAN KLAIM DALAM PELAKSANAAN JKN DIHUBUNGKAN DENGAN PERMENKES NOMOR 71 TAHUN 2013 TENTANG PELAYANAN KESEHATAN PADA JKN
}

\author{
Abdurrahman Hakim \\ Mahasiswa Program Pascasarjana Unisba \\ Program Studi Magister Ilmu Hukum \\ Email: doel911@gmail.com
}

\begin{abstract}
Abstrak- Dalam pelaksanaan kerjasama antara rumah sakit swasta dengan BPJS terdapat hal yang memberatkan rumah sakit sebagai provider BPJS, antara lain pembayaran klaim tagihan yang tertunda. Hal tersebut dapat menimbulkan kerugian dalam pengelolaan rumah sakit. Kerugian yang dialami oleh rumah sakit terdapat pada "cash flow" rumah sakit yang dapat mengakibatkan pelayanan terhambat dan memungkinkan terhentinya keberlangsungan rumah sakit. Tujuan dari penelitian ini adalah untuk mengatahui dan memahami perlindungan hukum terhadap hak rumah sakit swasta atas keterlambatan pembayaran klaim dihubungkan dengan Peraturan Menteri Kesehatan Nomor 71 Tahun 2013 Tentang Pelayanan Kesehatan pada Jaminan Kesehatan Nasional. Metode pendekatan yang digunakan dalam penelitian ini adalah yurudis normatif, spesifikasi penelitian yaitu deskriptif analitis dengan menganalisis data sekunder yang terdiri dari bahan-bahan hukum primer, bahan hukum sekunder, dan bahan hukum tersier yang diperoleh dari studi kepustakaan atau studi dokumenter, kemudian data yang diperoleh tersebut dianalisis menggunakan metode yuridis kualitatif. Hasil penelitian ini menunjukkan bahwa perlindungan hukum terhadap hak-hak rumah sakit swasta dalam pelaksanaan Jaminan Kesehatan Nasional diatur berdasarkan Peraturan Menteri Kesehatan Republik Indonesia Nomor 71 Tahun 2013 tentang Pelayanan Kesehatan Pada Jaminan Kesehatan Nasional, yang diwujudkan dalam perjanjian kerjasama antara rumah sakit dengan BPJS Kesehatan dalam Program Jaminan Kesehatan Nasional (JKN). Sementara itu, upaya-upaya hukum yang dapat dilakukan oleh rumah sakit swasta jika terjadi keterlambatan dalam pembayaran klaim dalam pelaksanaan jaminan kesehatan nasional yaitu penyelesaian sengketa melalui peradilan, penyelesaian sengketa nonperadilan, dan lembaga anjak piutang.
\end{abstract}

\section{Kata kunci: Perlindungan Hukum, Hak, Rumah Sakit, Pembayaran, Klaim}

Abstract- In implementing the collaboration between private hospitals and Healthcare
and Social Security Agency (BPJS), there are things that burden the hospitals as BPJS
providers, including delayed bill claim payments. This can cause losses in hospital
management. The loss experienced by the hospital is in the hospital's "cash flow" which
can result in hampered services and allow the cessation of the sustainability of the
hospital. This study aimed at knowing and understanding the legal protection of the
rights of private hospitals for late claim payment related to the Minister of Health
Regulation Number 71 Year 2013 concerning Health Services on National Health
Insurance. The study used normative juridical approach with analytical descriptive as
study specification by analyzing secondary data consisting of primary legal materials,
secondary legal materials, and tertiary legal materials obtained from literature studies or 
documentary studies. Then, the obtained data these were analyzed using qualitative juridical method. The result indicates that the legal protection of the rights of private hospitals in the implementation of the National Health Insurance is regulated based on the Regulation of the Minister of Health of the Republic of Indonesia Number 71 Year 2013 concerning Health Services in the National Health Insurance, which is manifested in a cooperation agreement between the hospital and BPJS Health in National Health Insurance (JKN) Program. Meanwhile, legal remedies that can be conducted by private hospitals if there are delay claim payment in the implementation of national health insurance, namely the settlement of disputes through the judiciary, settlement of nonjudicial disputes, and factoring institutions.

Keywords: Legal Protection, Rights, Hospitals, Payments, Claims

\section{A. Pendahuluan}

Undang-Undang No. 24

Tahun 2011 tentang Badan

Penyelenggara Jaminan Sosial

(BPJS) merupakan sebuah upaya

dari pemerintah dalam

melaksanakan asas pemerataan

dalam kesehatan sebagai wujud

tanggung jawab yang

diamanatkan dalam Undang

Undang 1945 dan Undang-

Undang No. 40 Tahun 2004

tentang Sistem Jaminan Sosial

Nasional (SJSN). Dengan adanya

BPJS diharapkan masyarakat

dapat menikmati pelayanan

kesehatan dari berbagai tingkat

ekonomi, dari yang

berkemampuan lebih sampai

kepada yang tidak mampu.

Rumah sakit sebagai
provider BPJS menghadapi beberapa hal teknis lain yang

memberatkan, antara lain

pembayaran klaim tagihan yang

tertunda dan dicicil, misalnya

klaim pada bulan Maret yang

belum lunas, dan klaim bulan Juni

yang sudah dibayar sebesar $10 \%$,

sehingga kesannya BPJS

membayar tanpa menunda. ${ }^{1}$ Hal

tersebut dapat menimbulkan

kerugian dalam pengelolaan

rumah sakit.

Ketua Perhimpunan

Rumah Sakit (PERSI) Kuntjoro

Adi Purjanto menyatakan arus kas

164 rumah sakit yang bekerja

sama dengan BPJS Kesehatan

terganggu akibat adanya klaim

biaya kesehatan yang belum

dibayar oleh BPJS Kesehatan

\footnotetext{
${ }^{1}$ http://www.pasiensehat.com/2015/09/keluh an-provider-rs-mengenai-bpjs-

kesehatan.html?m=1. Diakses pada tanggal 7 Juli 2017.
} 
dalam beberapa bulan terakhir. Data yang dihimpun PERSI, terdapat 41 rumah sakit swasta yang klaimnya sebesar Rp. 173 miliar belum dibayar. Di Jakarta ada 29 rumah sakit yang kalimnya sebesar Rp. 470 miliar belum dibayar. Rumah sakit yang klaimnya belum dibayar sebagian besar adalah rumah sakit tipe $\mathrm{C}$ dan D yang mayoritas pasiennya adalah peserta Jaminan Kesehatan Nasional-Kartu Indonesia Sehat $(\mathrm{JKN}-\mathrm{KIS})^{2}$

Kerugian yang dialami oleh rumah sakit terdapat pada cash flow rumah sakit. Hasil penelitian yang dilakukan oleh Akhmad Sobirin di salah satu rumah sakit daerah yang mengalami keterlambatan pembayaran klaim mengalami penundaan pembayaran kewajiban kepada pemasok bahanbahan/supplies yang dibutuhkan oleh rumah sakit. Hal tersebut mengakibatkan pelayanan terhambat dan memungkinkan

\footnotetext{
${ }^{2}$ Bertia Harian Kompas, 23 Nopember 2017
}

terhentinya keberlangsungan

rumah sakit. $^{3}$

Pembahasan hak dalam hal keterlambatan pembayaran klaim pada fasilitas kesehatan salah satunya adalah rumah sakit yang melakukan kerjasama sebagai provider dalam sistem Jaminan Kesehatan Nasional diatur dalam Peraturan Menteri Kesehatan Republik Indonesia Nomor 71 Tahun 2013 Tentang Pelayanan Kesehatan Pada Jaminan Kesehatan Nasional pada Bagian Ketiga tentang Hak dan Kewajiban dalam pasal 12 ayat (2), disebutkan salah satu hak fasilitas kesehatan adalah menerima pembayaran klaim atas pelayanan kesehatan yang diberikan Peserta paling lambat 15 (lima belas) hari kerja sejak dokumen klaim diterima lengkap. Bagaimana jika sampai beberapa bulan pihak BPJS belum membayar lunas pengajuan klaim dari rumah sakit setelah 15 hari,

${ }^{3}$ Akhmad Sobirin, Dampak Keterlambatan Pembayaran Klaim Jamkesmas Terhadap Cash Flow Rumah Sakit Daerah, www.lib.ui.ac.id dikases pada tanggal 7 Juli 2017. 
jika wanprestasi terjadi apakah upaya-upaya hukum yang dapat dilakukan oleh rumah sakit?

Berdasarkan hal tersebut perlu adanya perlindungan hukum terhadap rumah sakit dalam Sistem Jaminan Kesehatan Nasional. Oleh karena itu, penulis mengangkat judul "Perlindungan Hukum Terhadap Hak-Hak Rumah Sakit Atas Keterlambatan Pembayaran Klaim Dalam Pelaksanaan Jaminan Kesehatan Nasional Dihubungkan Dengan Peraturan Menteri Kesehatan Republik Indonesia Nomor 71 Tahun 2013 Tentang Pelayanan Kesehatan Pada Jaminan Kesehatan Nasional".

\section{B. Metode Penelitian}

1. Pendekatan

$$
\begin{aligned}
& \text { Pendekatan penelitian ini } \\
& \text { menggunakan pendekatan } \\
& \text { hukum normatif, yaitu } \\
& \text { penelitian yang dilakukan } \\
& \text { dengan cara meneliti bahan } \\
& \text { pustaka atau data sekunder } \\
& \text { belaka. }
\end{aligned}
$$

4 Soerjono Soekanto dan Sri Mamuji, Penelitian Hukum Normatif Suatu
2. Sifat Penelitian

Sifat penilitian ini adalah deskriptif analisis. Metode deskriptif dapat diartikan sebagai prosedur pemecahan masalah yang diselidiki dengan menggambarkan keadaan subjek atau objek dalam penelitian dapat berupa orang, lembaga, masyarakat dan yang lainnya yang pada saat sekarang berdasarkan faktafakta yang tampak atau apa adanya. ${ }^{5}$
Tinjauan Singkat, Raja Garfindo Persada, Jakarta, 2010. Hlm: 13-14.

${ }^{5}$ Moh. Nazir, Metode Peneltian,Ghalia Indonesia, Jakarta, 2009. Hlm. 63 
Jenis Data

Data yang diperoleh dan diolah dalam penelitian hukum normatif adalah data sekunder karena sumber data yang utama berasal dari sumber kepustakaan $^{6}$

3. Teknik Pengambilan Data

Bahan hukum yang dikaji dan dianalisis dalam penelitian hukum normatif, meliputi bahan hukum primer, sekunder, dan tersier. Teknik untuk mengkaji dan mengumpulkan ketiga bahan hukum itu, yaitu menggunakan studi dokumenter. Studi dokumenter merupakan studi yang mengkaji tentang berbagai dokumen, baik yang berkaitan dengan peraturan perundangundangan maupun dokumendokumen yang sudah ada. ${ }^{7}$

4. Teknik Analisa Data Kualitatif Teknik analisa data yang digunakan dalam penelitian hukum normatif menggunakan analisis kualitatif. ${ }^{8}$ Pengolahan

${ }^{6}$ Ibid. Hlm:13

${ }^{7}$ Ibid. Hlm:19.

${ }^{8}$ Ibid. bahan hukum dilakukan secara deduktif, yakni menarik kesimpulan dari suatu permasalahan yang bersifat umum untuk permasalahan yang bersifat konkret yang sedang dihadapi. Selanjutnya bahan hukum yang telah ada akan dianalisis untuk melihat bagaimana ketentuan hukum positif Indonesia yang mengatur mengenai perlindungan hukum terhadap hak-hak rumah sakit swasta atas keterlambatan pembayaran klaim dalam pelaksanaan Jaminan Kesehatan Nasional yaitu Peraturan Menteri Kesehatan Republik Indonesia Nomor 71 Tahun 2013 Tentang Pelayanan Kesehatan Pada Jaminan Kesehatan Nasional.

\section{Hasil dan Pembahasan}

1. Hasil

a. Keterlambatan

Pembayaran Klaim Yang Dilakukan Oleh BPJS Kepada Rumah Sakit Swasta Berdasarkan Peraturan Menteri 
Kesehatan Nomor 71

Tahun 2013 Tentang

Pelayanan Kesehatan

Pada Jaminan Kesehatan

Nasional.

Perjanjian kerjasama

antara rumah sakit dengan

BPJS Kesehatan dibentuk berdasarkan Peraturan

Menteri Kesehatan Nomor

71 Tahun 2013 tentang

Pelayanan Kesehatan pada

Jaminan

Kesehatan

Nasional Pasal 13, baik

pihak pertama maupun

pihak kedua yang tidak

dapat melaksanakan atau

terpaksa

menunda

pelaksanaan kewajibannya

dalam Perjanjian ini

disebabkan mengalami force

majeure, tidak dapat

dituntut kerugiannya oleh

pihak lain. Dengan syarat

pihak yang mengalami force

majeure memberitahu pihak

lain secara tertulis serta

membuktikan secara tertulis

resmi dari dinas setempat

bahwa telah terjadi

peristiwa force majeure yang menghalanginya

melaksanakan kewajiban

dalam perjanjian ini

sebagaimana diatur pada

Pasal 1244 dan 1245 KUH

Perdata. Pasal 1244 KUH

Perdata menjelaskan debitur

yang tidak membuktikan

diri bahwa sebab tidak

terlaksananya kewajiban

atau tidak pada waktunya

karena keadaan memaksa

maka debitur dihukum

untuk mengganti kerugian

yang ia timbulkan. Akan

tetapi jika debitur dapat

membuktikan dirinya

mengalami keadaan

mendesak sehingga tidak

bisa melaksanakan

kewajiban maka debitur tidak boleh dituntut atas kerugian tersebut dan ia dibebaskan dari kewajiban itu.

Selain itu, perjanjian kerjasama menyebutkan mengenai wanprestasi pada Peraturan Menteri Kesehatan Nomor 71 Tahun 2013 tentang Pelayanan 
Kesehatan pada Jaminan

Kesehatan Nasional Pasal

10 ayat (2) dan (3) tentang monitoring dan evaluasi serta Peraturan Menteri Kesehatan Nomor 71 Tahun 2013 tentang Pelayanan Kesehatan pada Jaminan Kesehatan Nasional Pasal 11 tentang sanksi. Peraturan Menteri Kesehatan Nomor 71 Tahun 2013 tentang Pelayanan Kesehatan pada Jaminan Kesehatan Nasional Pasal 10 ayat (2) menerangkan apabila dalam pelaksanaan hubungan kerja ini terjadi pelanggaran perjanjian atau wanprestasi oleh rumah sakit dan terbukti melanggar perjanjian kerjasama, BPJS Kesehatan memberi surat teguran yang menyatakan rumah sakit telah wanprestasi sehingga timbul kewajiban bagi rumah sakit untuk mengganti kerugian yang diakibatkannya.

$\begin{array}{rr}\text { Dalam } & \text { tahap } \\ \text { perundingan } & \text { naskah }\end{array}$

perjanjian kerjasama, yang terlibat adalah BPJS Kesehatan Pusat bersama PERSI (Persatuan Rumah Sakit Seluruh Indonesia) Pusat atas rekomendasi Kemenkes. Jadi, rumah sakit dalam proses perundingan isi naskah perjanjian kerjasama diwakili oleh PERSI Pusat. Isi dari perjanjian kerjasama mengikat para pihak dan isinya tidak menyimpang dari Permenkes. ${ }^{9}$

\section{b. Hubungan Hukum Antara BPJS dengan Rumah} Sakit Swasta

Salah satu wujud dari pelaksanaan fungsi dan kewenangan BPJS adalah melaksanakana hubungan perdata atau hubungan kontrak. Hubungan perdata atau hubungan kontrak adalah hubungan hukum yang timbul di antara dua

\footnotetext{
${ }^{9}$ Fitria Kusuma Wardania, Kabag. Umum dan SDM RSU Mulia Hati, Wawancara Pribadi, pada tanggal 20 Februari 2017 Pukul 09:00 WIB di Wonogiri. Dalam Nada Amalia Hasanah. Op. Cit.
} 
pihak atau lebih atas dasar kesepakatan yang dituangkan ke dalam perjanjian atau kontrak.

Pelaksanaan

perjanjian kerjasama antara rumah sakit dengan BPJS Kesehatan dalam Program Jaminan Kesehatan Nasional (JKN) berdasarkan Peraturan Presiden Nomor 12 Tahun 2013 yang menjadi landasan dilaksanakannya perjanjian kerjasama dalam program JKN dan Peraturan Menteri Kesehatan Nomor 71 Tahun 2013.

Hubungan hukum antara rumah sakit swasta dengan BPJS Kesehatan adalah hubungan kontraktual. Hubungan hukum antara Fasilitas Kesehatan dengan BPJS Kesehatan dibangun dari hubungan kontraktual melalui perjanjian kerja sama yang didasarkan pada Pasal 11 huruf e UU No. 24 Tahun 2011 di mana BPJS berwenang membuat dan menghentikan kontrak kerja dengan fasilitas kesehatan, dan Pasal 36 ayat (4) Perpres No. 12 Tahun 2013, yaitu fasilitas kesehatan milik Pemerintah yang telah memenuhi persyaratan wajib bekerja sama dengan BPJS Kesehatan yang dilaksanakan dengan membuat perjanjian tertulis.

\section{Pembahasan}

a. Perlindungan Hukum Terhadap Hak Rumah Sakit Swasta Atas Keterlambatan

Pembayaran Klaim dalam Pelaksanaan JKN Dihubungkan dengan Permenkes Nomor 71 Tahun 2013.

Perjanjian kerjasama antara rumah sakit dengan BPJS Kesehatan di seluruh wilayah Indonesia perjanjian kerjasama antara rumah sakit dengan BPJS Kesehatan dalam program JKN secara subtansi sama kecuali untuk daerah 
terpencil ada penambahan pasal karena keterbatasan fasillitas kesehatan. Pihak yang berwenang penuh melakukan perubahan terhadap substansi perjanjian kerjasama adalah BPJS Pusat dan PERSI Pusat berdasarkan rekomendasi dari Kementerian Kesehatan. Dalam tahap perundingan naskah perjanjian kerjasama, rumah sakit dalam proses perundingan isi naskah perjanjian kerjasama diwakili oleh PERSI Pusat. Isi dari perjanjian kerjasama mengikat para pihak dan isinya tidak menyimpang dari Permenkes. ${ }^{10}$

$$
\text { Dalam contoh }
$$

naskah perjanjian antara BPJS dan Rumah sakit yang telah diterbitkan oleh PERSI $^{11}$, tidak tampak

${ }^{10}$ Ibid.

${ }^{11}$ PERSI, Naskah Kerjasama Rumah Sakit dengan BPJS, 9 Desember 2013. www.pdpersi.co.id diakses pada tanggal 20 Desember 2017. secara tertulis perlindungan hak rumah sakit jika terjadi keterlambatan pembayaran. Beberapa pasal yang menyangkut tentang keterlambatan pemabayan antara lain:

Dalam perjanjian tersebut dapat disimpulkan bahwa keterlambatan dalam pembayaran klaim boleh dilakukan apabila dalam Keadaan memaksa (force majeure). Pada keadaan ini pihak BPJS boleh tidak membayarkan klaim jika terjadi bencana alam, banjir, wabah, perang (yang dinyatakan maupun yang tidak dinyatakan), pemberontakan, huru-hara, pemogokkan umum, kebakaran, dan kebijaksanaan Pemerintah yang berpengaruh secara langsung terhadap pelaksanaan Perjanjian ini. Dan semua kerugian yang terjadi selama force majeure tidak ditanggung oleh BPJS. Pernyataan dalam pasal 13 
ayat 1 ini bisa diartikan bahwa selama keadaan force majeure, rumah sakit tidak dapat menuntut pihak BPJS untuk melaksanakan kewajibannya dalam hal pembayaran klaim. Jadi selama keadaan force majeure rumah sakit tidak bisa menuntut hak pembayaran klaim terhadap BPJS.

Jika keadaan force majeure berlangsung lama, dalam pasal 13 ayat 2 dalam perjanjian ini yaitu lebih dari 30 hari kalender, maka pihak rumah sakit dan BPJS akan meninjau kembali jangka waktu perjanjian ini. Dalam ayat ini tidak dijelaskan batas maksimal dan bagaimana pembayaran klaim selama masa force majeure akan dilunasi. Jika ini terjadi dan semua kerugian yang diderita selama masa force majeure bukan merupakan tanggung jawab Pihak yang lain, dalam hal ini adalah BPJS sebagaimana ayat 3 pasal 13 dalam perjanjian ini, maka jelas kerugian yang terbesar akan dialami oleh pihak rumah sakit.

Dalam perjanjian tidak dituliskan kompensasi yang diberikan atau denda yang harus dibayarkan dari keterlambatan pembayaran tagihan klaim. Padahal dengan adanya keterlambatan pembayaran klaim rumah sakit mengalami kesulitan dalam pembiayaan operasional bahkan mungkin harus mencari sumber biaya lain yang harus dipakai sampai tagihan pada pembayaran klaim dilunasi oleh BPJS. Sumber biaya tersebut biasanya didapatkan melalui pinjaman-pinjaman kepada lembaga keuangan. Jika pinjaman tersebut menghasilkan bunga yang cukup besar, maka selama masa pinjaman bunga tersebut akan makin membesar pula. Jika hal ini 
terjadi, dari manakah bunga tersebut akan dibayarkan selain rumah sakit harus mengefisiensikan anggaran yang ada.

Ketiadaan biaya denda yang dikenakan bagi BPJS yang melakukan keterlambatan dalam pembayaran tagihan klaim dari rumah sakit, menyalahi Peraturan Presiden Republik Indonesia Nomor 19 Tahun 2016 Tentang Perubahan Kedua Atas Peraturan Presiden Nomor 12 Tahun 2013 Tentang Jaminan Kesehatan Pasal 38 Ayat (2) BPJS Kesehatan wajib membayar ganti rugi kepada Fasilitas Kesehatan sebesar $1 \%$ (satu persen) dari jumlah yang harus dibayarkan untuk setiap 1 (satu) bulan keterlambatan. Dalam peraturan tersebut telah ditegaskan bahwa BPJS Kesehatan wajib membayar ganti rugi kepada Fasilitas Kesehatan sebesar $1 \%$ (satu persen) dari jumlah yang harus dibayarkan untuk setiap 1 (satu) bulan keterlambatan. Hal ini secara tegas mewajibkan pembayaran denda sebesar $1 \%$, mungkin juga sesuai dengan perhitungan bunga pinjaman yang mungkin akan diberikan oleh lembaga keuangan kepada rumah sakit.

Selain tidak dituliskan tentang denda, dalam perjanjian tersebut tidak ditentukan batas waktu maksimal yang menjadi batas akhir dari keterlambatan pembayaran klaim. Keterangan batas waktu maksimal juga dapat membantu rumah sakit dalam menentukan kebijakan pada saat anggaran, jika terjadi keterlambatan pembayaran klaim. Dengan adanya adanya ketentuan batas waktu juga rumah sakit dapat memperkirakan anggaran yang harus 


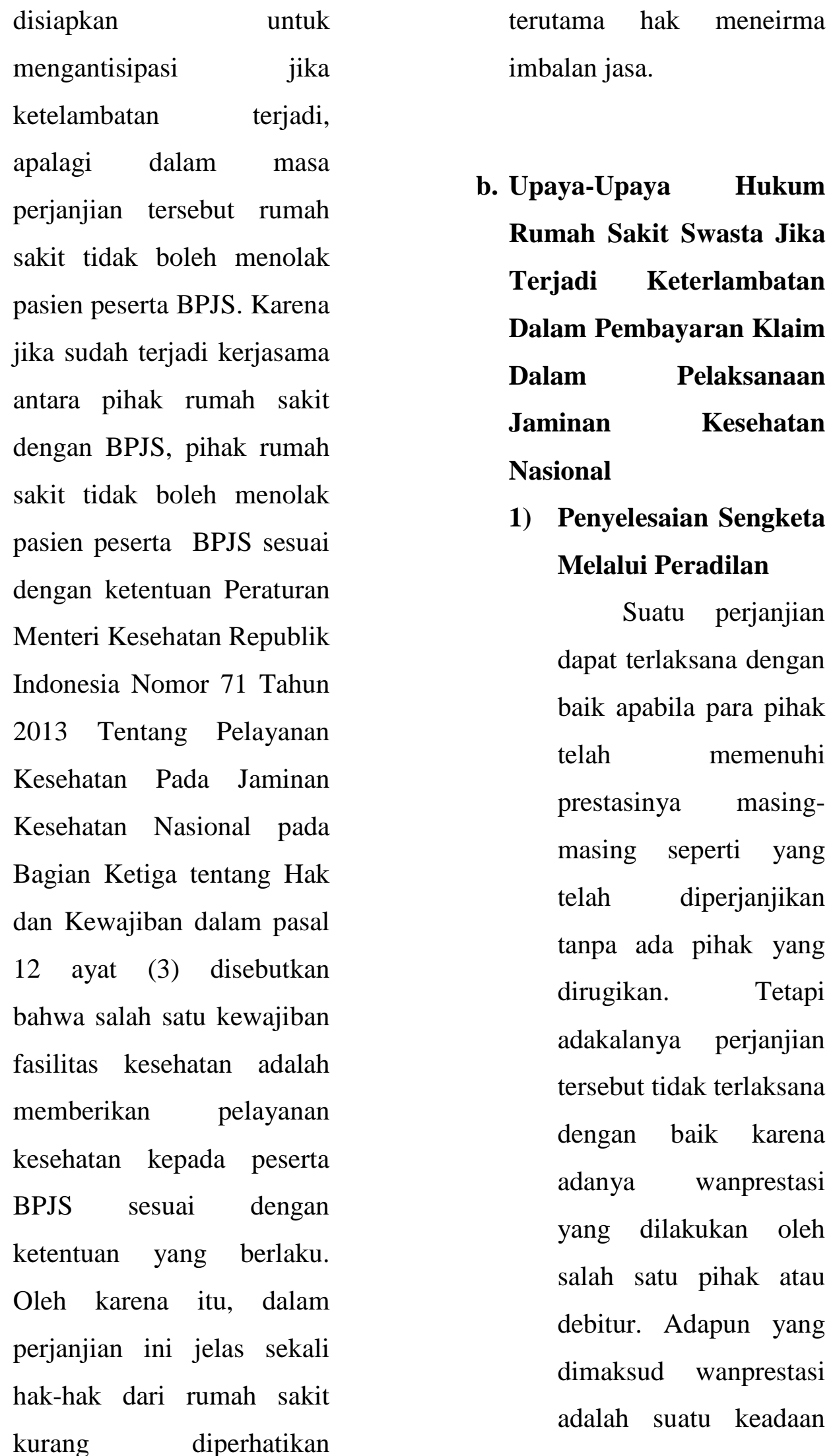




yang dikarenakan
kelalaian atau
kesalahannya, debitur
tidak dapat memenuhi
prestasi seperti yang
telah ditentukan dalam
perjanjian ${ }^{12}$ dan bukan
dalam keadaan
memaksa. Adapun
bentuk-bentuk dari
wanprestasi yaitu: ${ }^{13}$

a) Tidak memenuhi prestasi sama sekali;

b) Memenuhi prestasi tetapi tidak tepat waktunya;

c) Memenuhi prestasi tetapi tidak sesuai atau keliru.

Apabila tidak ditentukan mengenai batas waktunya maka untuk menyatakan seseorang debitur melakukan wanprestasi, diperlukan surat peringatan tertulis dari

${ }^{12}$ Nindyo Pramono, Hukum Komersil, Pusat Penerbitan UT, Jakarta, 2003. Hlm. 2.21

13 R. Setiawan, Pokok-Pokok Hukum Perjanjian, Putra Abadin, Jakarta, 1999. Hlm. 18 kreditur yang diberikan kepada debitur. Surat peringatan tersebut disebut dengan somasi.

Somasi adalah pemberitahuan atau pernyataan dari kreditur kepada debitur yang berisi ketentuan bahwa kreditur menghendaki pemenuhan prestasi seketika atau dalam jangka waktu seperti yang ditentukan dalam pemberitahuan itu. Menurut pasal 1238 KUH Perdata yang menyakan bahwa: "Si berutang adalah lalai, apabila ia dengan surat perintah atau dengan sebuah akta sejenis itu telah dinyatakan lalai, atau demi perikatan sendiri, ialah jika ini menetapkan bahwa si berutang harus dianggap lalai dengan lewatnya waktu yang ditentukan". 
2) Penyelesaian Sengketa Non-Peradilan

Peraturan Menteri

Kesehatan No. 28

Tahun 2014 telah

memfasilitasi

penyelesaian sengketa

melalui mediasi oleh

Tim Monitoring-

Evaluasi

Penyelenggaraan

Pelayanan JKN (Tim

Monev), yang berada

dan dilakukan secara

berjenjang mulai

tingkat

Kabupaten/Kota,

Provinsi, hingga Pusat.

Dalam hal sengketa

tidak dapat diselesaikan

oleh Tim Monev Pusat

maka

Menteri

Kesehatan dapat

menjadi mediator dalam

proses mediasi tersebut.

Tim Monev tingkat

Kabupaten/Kota dan

provinsi ditetapkan oleh

Pemerintah Provinsi

melalui

Dinas

Kesehatan

Provinsi sedangkan Tim Monev

tingkat Pusat ditetapkan

oleh

Menteri

Kesehatan.

Ada

pendapat

bahwa

mediator

dari

Pemerintah akan tidak

jelas dan dapat

dimainkan untuk

kepentingan pribadi $^{14}$,

untuk itu dalam

penyelesaian sengketa

JKN mediator

Pemerintah diperlukan

sifat independensi dari

Pemerintah sendiri yang

bertujuan melindungi

kepentingan

masyarakat.

$\begin{array}{cc}\text { Pada } & \text { dasarnya } \\ \text { penyelesaian } & \text { sengketa }\end{array}$

alternatif melalui

mediasi oleh Tim

Monev dan Menteri

Kesehatan tersebut

${ }^{14}$ H. Astor. Mediator Neutrality: Making Sense of Theory and Practice. Sydney Law School, Legal Study Research Paper No. 07/46. Hlm. 3. Dalam Asep Kusnali, dkk, Fungsi Kelembagaan Independen Dalam Penguatan Mekanisme Penyelesaian Sengketa Jaminan Kesehatan Nasional, Buletin Penelitian Sistem Kesehatan Vol. 19 No. 4 Oktober 2016, hlm: 250-257 
telah mendekati hakikat

independensi. Namun

memaknai

'independensi' tidak

dapat disamakan

dengan

prinsip

netralitas dari mediasi.

Penyelenggaraan

JKN telah melahirkan

hubungan hukum yang

beragam dan dapat

berimplikasi pada

sengketa yang

melibatkan berbagai

lembaga penyelesaian

sengketa yang berbeda

dari setiap hubungan-

hubungan hukum yang

terjadi.

Dalam rangka

upaya pencegahan,

deteksi dan penindakan

kecurangan JKN,

Permenkes No. 36

Tahun

memberikan ruang

untuk melakukan

penyelesaian sengketa

perselisihan dalam hal

terjadi penetapan

kecurangan berdasarkan hasil investigasi Tim

Pencegahan

Kecurangan JKN

melalui tahapan

pengaduan yang

dilakukan secara tertulis

yang disampaikan

kepada pimpinan

fasilitas kesehatan,

Dinas Kesehatan

Kabupaten/Kota

dan/atau Dinas

Kesehatan Provinsi.

3) Usaha

Anjak

Piutang/Factoring ${ }^{15}$

Perusahaan Anjak

Piutang merupakan

alternatif pembiayaan

untuk memperoleh

modal pendanaan dalam

melakukan kegiatan

usaha. Keberadaan

perusahaan anjak

piutang sebagai

alternatif bagi penjual

untuk secepatnya

mendapatkan uang

tunai atau mendapatkan

${ }^{15}$ Indra Kesuma Hadi, Mekanisme

Pengalihan Piutang Dalam Perjanjian

Factoring. Kanun Jurnal Ilmu Hukum No. 66, Th. XVII (Agustus, 2015), pp. 327-340. 


\begin{tabular}{|c|c|}
\hline pembiayaan & Pengertian anjak \\
\hline baru dalam bentuk & dipertegas \\
\hline instant. Hal ini untuk & kembali di \\
\hline menjaga peredaran kas & Peraturan \\
\hline (cash flow) perusahaan & Keuangan \\
\hline penjual akibat dari & 84/PMK.012/2006 \\
\hline pembayaran berjangka & Perusahaan \\
\hline dari pembeli. & Pembiayaan. Pasal 1 \\
\hline Di Indonesia, & huruf (e) berbunyi: \\
\hline anjak piutang pertama & Anjak \\
\hline sekali dikenal diatur di & (Factoring) adalah \\
\hline dalam Keppres No. 61 & kegiatan pembiayaan \\
\hline Tahun 1988 tentang & dalam \\
\hline Lembaga Pembiayaan. & pembelian \\
\hline Pasal 1 ayat (8) & dagang jangka pendek \\
\hline Keppres No. 61 Tahun & perusahaan \\
\hline 1988 menyatakan, & berikut pengurusan atas \\
\hline perusahaan anjak & tersebut. \\
\hline (factoring & Kegiatan anjak piutang \\
\hline company) adalah badan & tersebut \\
\hline usaha yang melakukan & dilakukan dalam bentuk \\
\hline pembiayaan & Anjak Piutang tanpa \\
\hline dalam & jaminan dari Penjual \\
\hline pembelian & Piutang \\
\hline pengalihan & Recourse) dan Anjak \\
\hline pengurusan & Piutang dengan jaminan \\
\hline atau tagihan jangka & dari Penjual Piutang \\
\hline pendek & Recourse), \\
\hline perusahaan & sebagaimana \\
\hline transaksi perdagangan & disebutkan dalam Pasal \\
\hline dalam atau luar negeri. & 4 ayat (2) peraturan \\
\hline
\end{tabular}




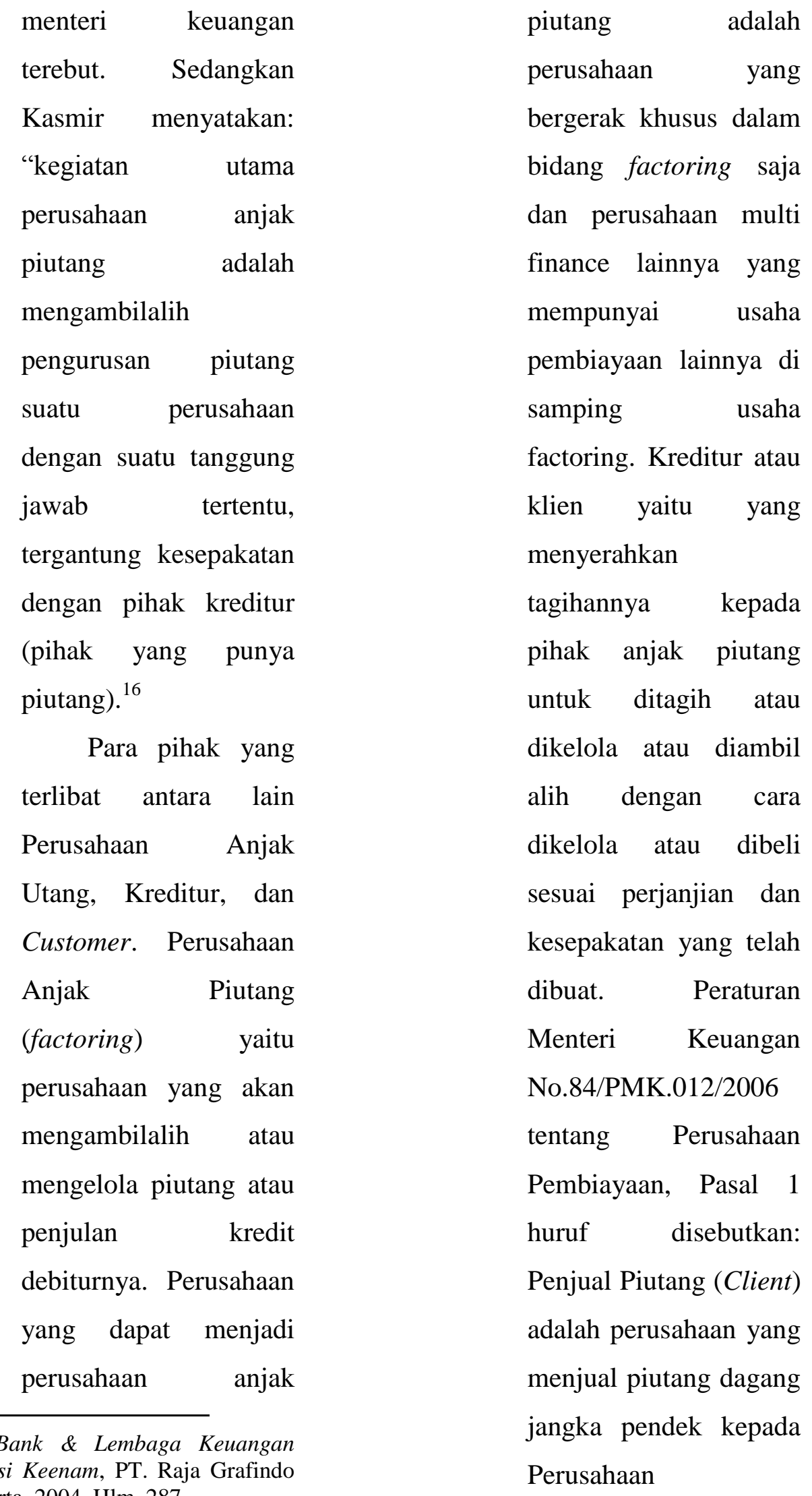

${ }^{16}$ Kasmir, Bank \& Lembaga Keuangan Lainnya, Edisi Keenam, PT. Raja Grafindo Persada, Jakarta, 2004. Hlm. 287. 
Pembiayaan. Customer yaitu pihak Debitur yang berutang kepada klien.

Customer merupakan unsur yang penting, karena customerlah yang akan melunasi pembayaran kepada perusahaan anjak piutang, customer juga yang menentukan macet tidaknya tagihan.

Piutang yang merupakan objek bisnis factoring adalah apa yang disebut dengan piutang dagang. Yaitu tagihan-tagihan bisnis yang belum jatuh tempo (account receivable), baik yang dikeluarkan dengan memakai surat berharga, seperti Promissory Notes, atau hanya berupa tagihan lewat invoice dagang biasa. Jadi factoring bukan ditujukan terhadap piutang yang sudah macet. ${ }^{17}$

Piutang dagang yang biasa menjadi objek factoring, sebagai berikut:

a) Piutang yang terdiri dari seluruh tagihan berdasarkan invoiceinvoice dari suatu perusahaan yang belum jatuh tempo;

b) Piutang yang timbul dari surat-surat berharga yang belum jatuh tempo;

c) Piutang yang timbul dari suatu proses pengiriman barang. Jadi sebagai pengganti $\mathrm{L} / \mathrm{C}$;

d) Piutang yang merupakan tagihantagihan yang belum jatuh tempo. Misalnya yang terbit dari penggunaan kartu kredit, biro

\footnotetext{
${ }^{17}$ Munir Fuady, Hukum tentang Pembiayaan dalam Teori dan Praktek, PT. Citra Aditya Bakti, Bandung, 2002. Hlm. 72.
} 


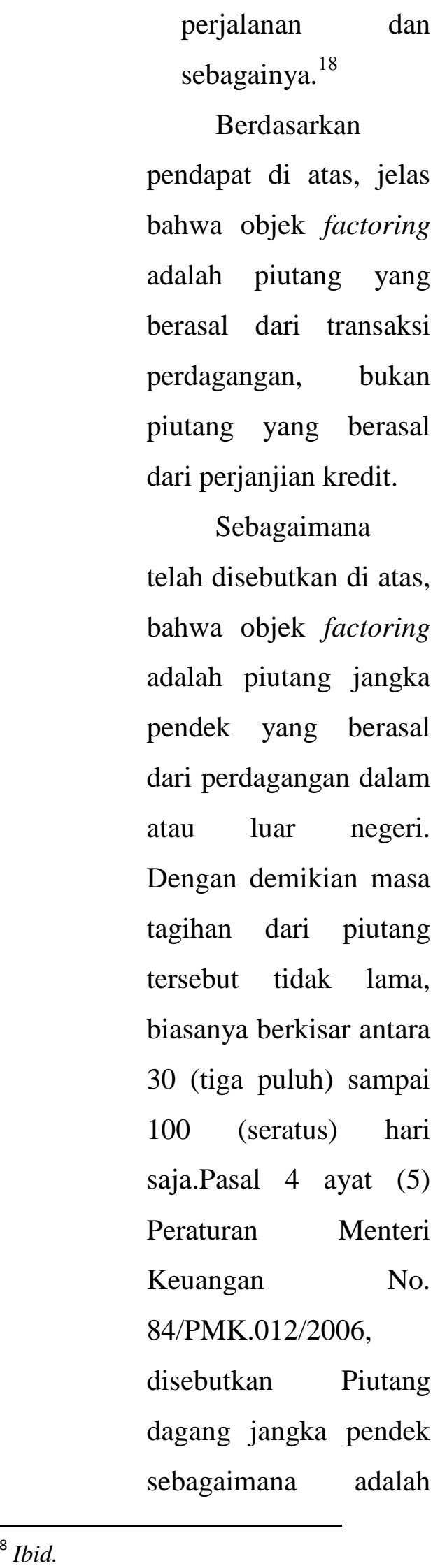




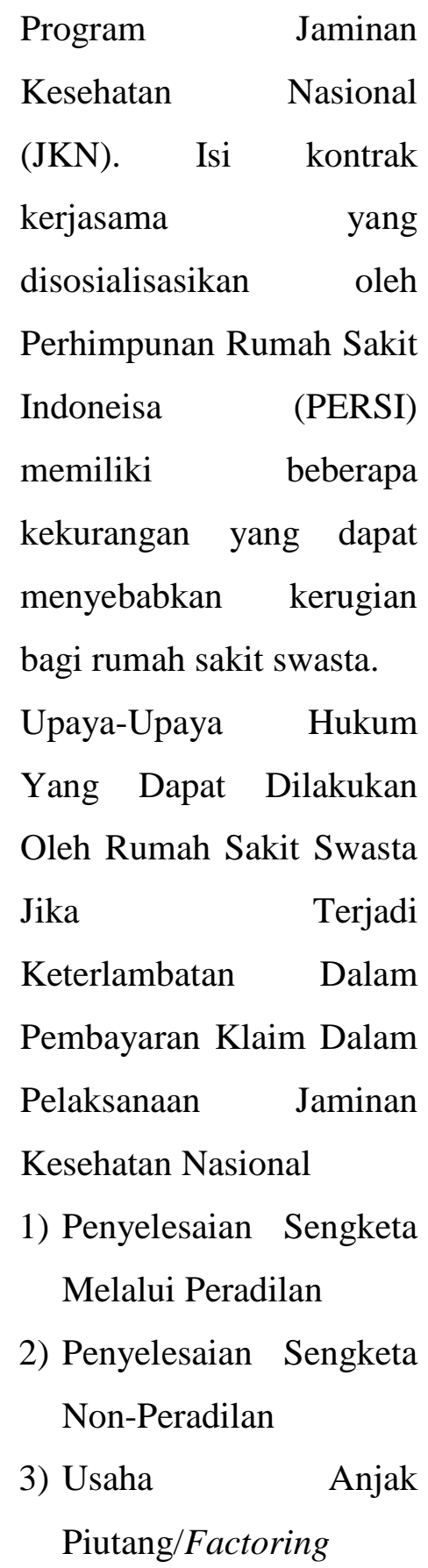

2. Saran

Rumah Sakit hendaknya melaksanakan upaya-upaya hukum yang dapat dilakukan jika terjadi keterlambatan pembayaran klaim. Upaya hukum yang dapat dilakukan dapat berupa penyelesaian sengketa melalui peradilan, penyelesaian sengketa nonperadilan, dan lembaga/usaha anjak piutang/factoring.

\section{E. Daftar Pustaka}

\section{Buku}

Moh. Nazir, Metode Peneltian, Ghalia

Indonesia, Jakarta, 2009.

Nindyo Pramono, Hukum Komersil, Pusat Penerbitan UT, Jakarta, 2003.

Kasmir, Bank \& Lembaga Keuangan Lainnya, Edisi Keenam, PT. Raja Grafindo Persada, Jakarta, 2004. Hlm.

Munir Fuady, Hukum tentang Pembiayaan dalam Teori dan Praktek, PT. Citra Aditya Bakti, Bandung, 2002. Hlm.

R. Setiawan, Pokok-Pokok Hukum Perjanjian, Putra Abadin, Jakarta, 1999. 
Soerjono Soekanto dan Sri

Mamuji, Penelitian Hukum

Normatif Suatu Tinjauan

Singkat, Raja Garfindo

Persada, Jakarta, 2010.

\section{Skripsi}

Nada Amalia Hasanah, Pelaksanaan Hubungan Kerja Antara Rumah Sakit dengan BPJS Kesehatan dalam Program Jaminan Kesehatan Nasional. Skripsi. Universitas Muhammadiyah Surakarta. 2017.

\section{Jurnal}

Indra Kesuma Hadi, Mekanisme Pengalihan Piutang Dalam Perjanjian Factoring. Kanun Jurnal Ilmu Hukum No. 66, Th. XVII. Agustus, 2015.
Internet

\begin{aligned} Akhmad $\quad$ Sobirin, & Dampak \\ \hline $\begin{array}{l}\text { Keterlambatan } \\ \text { Pembayaran }\end{array} &$ Klaim \\ \hline Jamkesmas & Terhadap \\ \hline Cash Flow & Rumah Sakit \\ & Daerah, www.lib.ui.ac.id \\ & dikases pada tanggal 7 Juli \\ & 2017. \end{aligned}

http://www.pasiensehat.com/2015

/09/keluhan-provider-rs-

mengenai-bpjs-

kesehatan.html?m=1.

Diakses pada tanggal 7

Juli 2017.

PERSI, Naskah Kerjasama Rumah Sakit dengan BPJS, 9 Desember 2013. www.pdpersi.co.id diakses pada tanggal 20 Desember 2017. 